\title{
Analysis of Employee Recruitment in Improving Performance in the Accommodation Service Business
}

\author{
Muhammad Yusuf \\ Politeknik Pariwisata Makassar \\ Email: yusufsaharuna@gmail.com
}

\begin{abstract}
The economic development of a region, especially in the development of the tourism sector, cannot be separated from the development of its human resources. This study aims to see the employee recruitment system, employee performance, and employee education qualifications at hotels in the city of Parepare. 7 informants are leaders and/or employees who are taken from hotels who are deemed to be able to represent the whole hotel in Parepare City. This research is applied research with a qualitative approach. Data were analyzed descriptively. Observations were made at seven hotels as the object of research, one of which recruited employees openly, while the other six hotels did not. Of all employees in the seven hotels, only a small proportion have educational qualifications with a tourism background. There is one hotel that has employees with a tourism education background, but only at the level of vocational high school education, besides that employee performance is generally still low in almost all hotels, only one hotel which according to our observations is quite good in terms of hotel service standards. The results showed that the recruitment system has not been implemented openly, employee performance is still low and educational qualifications are not following the needs of the workforce in the hotel industry.
\end{abstract}

Keywords: Recruitment, performance, hospitality

\section{INTRODUCTION}

The tourism sector is a sector that is used as one of the sectors most relied on by almost all countries in the world to improve the economy of countries such as Thailand (Forsyth, 1995; Kontogeorgopoulos et al., 2014; Sriprasert et al., 2014; Yousaf \& Xiucheng, 2018), Portugal (Almeida Garcia, 2014; Andraz et al., 2015; Cunha, 2011), South Africa (Binns \& Nel, 2002; Rogerson, 2006; Saayman et al., 2012; Walker et al., 2013), and Indonesia. The current government has made the tourism sector the core of the national economy, this was stated by the president of the Republic of Indonesia at several cabinet meetings including at the cabinet meeting on December 7, 2016, that the tourism sector helps the movement of the Indonesian economy (Indonesia, 2016).

The economic development of a region, especially in the development of the tourism sector, cannot be separated from the development of its human resources (Arhas \& Suprianto, 2020). South Sulawesi is no exception, which has also begun to take advantage of the potential for regional tourism to be developed, especially in the City of Pare-Pare, but it has not been fully supported by qualified human resources. Also, developing tourism destinations cannot be separated from other supporting facilities such as accommodation businesses. The accommodation service business sector is a major requirement that exists in tourism products (Culpan, 1987; Light \& Dumbrăveanu, 1999; Sheldon, 1989), then, of course, it will force these efforts to always improve the quality of service to guests who use these accommodation services

Copyright (C) 2021 Universitas Negeri Makassar. This is an open access article under the CC BY license (http://creativecommons.org/licenses/by/4.0/) 
60 Jurnal Administrare: Jurnal Pemikiran Ilmiah dan Pendidikan Administrasi Perkantoran

Volume 8 Issue 1, January-June 2021. Pages 59-68

(Ernawati et al., 2019; McGuffie, 1994). Thus, employee performance is also required to always develop themselves through education and training (Dahlan et al., 2017; Ibrahim et al., 2017; Rakib et al., 2016; Schubnell et al., 2008; Waris, 2015). Seeing the quality of an accommodation service product cannot be seen from one point of view but from various points of view, including in this case the knowledge, skills, and attitudes of the workers themselves. Service products sold by hotels have the same level from one hotel to another, not necessarily that customers/guests will feel the same level of satisfaction received from different hotels (Bojanic, 1996; Levitt, 1981; Liu \& Zhang, 2014), rather it is determined by the added value that guests get from hotel employees with different levels of service quality to the guests of each hotel. Sujatno (2011) argues that the importance of a caring attitude is more than just a serving attitude. The services provided by employees to their guests are not just fulfilling their duties and responsibilities following the Standard Operation Procedure (SOP)(Kencana, 2020; Nur \& Seran, 2020) only that which has been determined and implemented quickly and correctly, but more than that the service should be given sincerely and sincerely even beyond what the guests expect and should receive (Browning et al., 2013; Rao, 2013; Tsang \& Qu, 2000). The service meant here is to give more attention to the guests so that they feel something extraordinary that they did not expect before, thus, they will be touched by the service they get from hotel employees where they use the hotel services.

Pare-pare is a city that is geographically very strategic because it is a city crossing from various directions, either north to south or vice versa or the east of South Sulawesi Province, so the city of Pare-pare can be said to be a transit city. Because of its role as a transit city, the local government needs accommodation facilities in the city of Pare-Pare to support accommodation services for guests/tourists who happen to cross or who deliberately visit with various purposes of their visit.

\section{METHOD}

This research is applied research with a qualitative approach. This research was conducted in the City of Parepare, South Sulawesi. The informants in this study were 7 leaders and employees who were taken from the hotel who were considered to represent the whole hotel in the city of Parepare. The data collection techniques used in this study were: observation and in-depth interviews. The data analysis technique used descriptive analysis. Information that has been obtained through interviews and observations is arranged, compiled, and then presented in a form that is easy to read and understand for others who need it. Furthermore, data reduction is carried out, namely selecting data, simplifying and focusing data, summarizing data, and transforming raw data. The meaning of data reduction is done by reading interview transcripts, notes on observations, or documents to be analyzed. In the final section, the researcher groups (clustering) the data according to their respective types or according to the problems in the problem formulation, namely related to the recruitment process for hotel employees, hotel employee qualifications, and the performance of hotel employees in Pare-pare City. 


\section{RESULT AND DISCUSSION}

There are 29 hotels registered with the Youth, Sports, and Tourism Office in the City of Parepare, which are spread over three sub-districts. Of the twenty-nine hotels, we took 10 hotels that were considered to be representative, both in terms of the number of workers and from the aspect of quality of the hotels where they worked. Of the ten hotels we visited, three hotels were not willing to be asked for interviews or asked for the data we wanted. However, the data we collected from the seven hotels that we can collect is sufficient to represent in general the condition or state of tourism human resources (employees) in the City of Parepare.

Table 1.

Number of Rooms and Hotel Employees in the City of Parepare

\begin{tabular}{clccc}
\hline \multirow{2}{*}{ Number } & \multirow{2}{*}{ Hotel Name } & \multirow{2}{*}{ Number of Room } & \multicolumn{2}{c}{ Number of employees } \\
\cline { 4 - 5 } & & 19 & 12 & Female \\
\hline 1. & Satria Wisata & 36 & 3 & 9 \\
2. & Grand Kartika & 35 & 15 & 3 \\
3. & Bukit Kenari & 49 & 14 & 15 \\
4. & Parewisata & 52 & 6 & 8 \\
5. & Graha Indah & 19 & 8 & 4 \\
6. & Hotel 88 & 45 & 14 & 6 \\
7. & Pare Beach & 37 & 20 & 8 \\
8. & Delima Sari & 13 & 6 & 20 \\
9. & Mario & 26 & 8 & 4 \\
10. & Bugis & $\mathbf{3 3 1}$ & $\mathbf{1 0 6}$ & $\mathbf{8 6}$ \\
\hline
\end{tabular}

Source: Youth, Sports and Tourism Office of the City of Parepare, 2020

\section{Employee Recruitment System}

The recruitment system for hotel employees in the city of Parepare differs from one another, some are open announcements and are only called for interviews but more admissions are carried out in private, meaning that there are no public announcements but the only word of mouth to close people. who get the information in the employee recruitment. Employee recruitment that is carried out not openly will certainly have an impact on the expected quality of employees because there will be a limited number of people who will take the employee acceptance test concerned.

Hotel Satria Wisata has 21 employees from various general educational backgrounds starting at the undergraduate level, public high schools and Vocational High Schools. Employees owned by this hotel are the results of acceptance through tests even though the employee recruitment process is not publicly announced. Furthermore, Grand Kartika Hotel, which is located in the city center, is fairly clean, but physically the hotel building is classified as a small hotel. This hotel in the recruitment of employees also goes through a test but it is not announced publicly so that it is feared that employees who have been recruited will not get employees who match the competencies required by the hotel. The recruitment of employees carried out by the Bukit Kenari hotel is also the same, namely carrying out tests but not making public announcements like other hotels in Pare-Pare so of course it is difficult to find employees 


\section{Jurnal Administrare: Jurnal Pemikiran Ilmiah dan Pendidikan Administrasi Perkantoran Volume 8 Issue 1, January-June 2021. Pages 59-68}

who match the needs of the hotel concerned, especially from workers who tourism education background.

Hotel Parewisata, which is located in the center of trade with 22 employees, is a hotel that physically does not appear to be a hotel because it is located and integrated with other trading shop buildings. This hotel in employee recruitment is carried out openly, meaning that prospective employees are immediately summoned for interviews, if they are considered good and competent, they are accepted according to hotel standards and criteria. Furthermore, Graha Indah Hotel is a physically large building compared to hotels in the City of Parepare. This hotel also recruits employees openly where prospective employees are immediately summoned for interviews, if deemed appropriate they will be accepted to work at the hotel. Meanwhile, hotel 88 carries out employee recruitment and also conducts tests, it's just that the desired employee performance standard is not stated so it is difficult to say that what is received is following the desired employee performance standard or not. The requirements for hiring employees are not determined, educational background is not determined, this can be seen in some 88 hotel employees that none of them has a tourism education background, either high school or higher tourism education.

Hotel Pare Beach is in the same condition as hotel 88 where physically the hotel is in the form of a shophouse so that it looks like it is not a hotel from afar. However, according to our observations, the Pare Baech hotel is somewhat better in employee acceptance because those received are prioritized from vocational high schools and other hotel schools, and after being declared graduated, they are provided with education and training. Meanwhile, the Bugis hotel, the Delima Sari hotel, and the Mario hotel were hotels that were not willing to be asked for the data we needed, so we could not assess in depth what and how in the employee recruitment system at the three hotels. However, if we look at what we have observed in hotels in the city of Parepare, it can be concluded that the recruitment system for employees of the three hotels is not much different from the hotels that have been studied.

\section{Employee Performance}

The ability to carry out the duties of an employee cannot be separated from an employee recruitment process as previously discussed. Hotel Satria Wisata has 21 employees with various educational backgrounds, from the undergraduate level, public high schools, and vocational high schools (SMK). With the employee recruitment system that is carried out as stated and following the observations that have been made, it can be said that employees work not following their respective duties and responsibilities. This can be seen clearly in a visible opportunity where employees are seen gathering and working with topics of conversation not related to their job duties but something outside their work. Under these conditions, it can be said that the hotel will not display the skills and skills that match the standards of a hotel.

Grand Kartika Hotel has 6 employees, therefore it requires a workforce that is truly capable of carrying out their duties and responsibilities effectively and efficiently because of the imbalance between the number of rooms and the number of employees available. Under these conditions, the hotel manager sometimes doubles as a receptionist on duty at the front office. Seeing conditions like this, of course, we cannot make the most of employees, especially with limited abilities. In addition to their limited abilities, none of the employees have a tourism education background, either from a high school level, let alone from a tourism university. Meanwhile, amid the Covid-19 pandemic, Hotel Bukit Kenari has laid off more than 50\% of its 
employees of 30 employees. The employees owned by this hotel are predominantly high school graduates and work as is, they work according to their respective positions that have been occupied for a long time because they work not only in one section, sometimes they work in one section but at other times work in a division. another, so that there is almost no employee transfer from one section to another. This hotel is a hotel that is a bit old so that its employees also have a lot of experience and have attended training, it's just that there seems to be no change in service quality, including appearance, for example, it is difficult to distinguish between employees and guests because employees do not wear work uniforms. Besides that, in terms of service in the room, sometimes damaged facilities and/or equipment are not a concern, including the provision of consumable materials, for example, drinking water in the room, if a guest stays more than 1 day, then the next day drinking water is not added in the room. if guests don't ask for it. Things like this seem trivial but have an impact on the impression of staying guests that they feel they are not being served properly as the standard of a hotel, which in turn will bring a bad image to the hotel itself.

Hotel Parewisata has shown a representative hotel standard with the existence of an organizational structure in the hotel, although not hierarchically as a good hotel. In terms of educational qualifications, the employees are all from public schools at both high school and university levels, although none of them has a tourism education background. However, on the positive side, employees who are hired before they do their job are trained first before they are officially accepted to work as permanent employees. Their performance standards are outlined in the form of standard operating procedures (SOPs). Furthermore, Hotel Graha Indah has a total of 10 employees. This number is quite small compared to the number of rooms of 52 rooms. This of course requires employees who have good quality because they are required to perform well, but in reality, this is not what we see. Employees don't seem to have clear responsibility for what work to do, which to do. Every employee can do whatever can be done even though the job is not / is not within the scope of his / her responsibility. The employees on duty are not clear which employees are and which are guests because the employees are not wearing work uniforms. These things are a note of improvement at this hotel, especially service companies such as hotels that require 24-hour handling.

Employee recruitment at Hotel 88 continues to carry out tests even though the test does not specify what requirements and what educational background are required for the recruitment of employees. This is evidenced by the fact that all employees owned by this hotel are all from high school public education schools. In the recruitment of employees, there is also no desired performance standard for the employee so it is difficult to say whether what is received is following the employee's performance standard or not. Because our observations of what the employees show, although at first glance it does not seem to reflect as a hotelier, for example, from his appearance that is not wearing an employee work uniform, and there is absolutely no initiative to welcome every guest who comes. Furthermore, Pare Beach Hotel is a hotel with its physical building condition, which is a shopping model. However, according to our observations, the Pare Baech hotel is somewhat better managed than the other hotels in Parepare. In terms of employee performance, this hotel is quite good in that the employees are attentive to the guests, for example after the guest checks in, the guest is offered to pick up guest items and take them directly to the guest room where the guest room is located.

Hotel Bugis, hotel Delima Sari, and hotel Mario are hotels that are not willing to be asked by the data we need, so we cannot assess in depth what and how the services available at the 


\section{Jurnal Administrare: Jurnal Pemikiran Ilmiah dan Pendidikan Administrasi Perkantoran Volume 8 Issue 1, January-June 2021. Pages 59-68}

three hotels. However, if we look at the circumstances that we see, Bugis hotels are the most hostile towards guests, they are very disrespectful of the guests who come without feeling guilty, when we entered the hotel some employees were working cleaning the floors and some employees passing by doing work in the hotel repairing damaged equipment. Likewise, at Mario's hotel, service to guests is also not optimal as the reception of guests who come to the hotel is not considered as befits a hotel.

\section{Discussion}

Employees are a key element of the organization. The success or failure of the organization depends on employee performance. Therefore, the organization invests a large amount of money in employee development. Recruitment and selection, as a function of human resource management, are among the activities that have the most critical impact on organizational performance in terms of achieving goals. (Chow \& Chapman, 2013). Quality human resources are generally born through quality training and development processes. Realizing that the dominant factor in the continuity of company activities, in this case, the company needs to improve the quality of human resources and increase attention to what employees need so that employee performance will increase. Human resource planning in a company aims to improve employee performance for the implementation of company goals. One of these plans is to prepare human resources, explore their potential by recruiting and selecting employees who will be accepted into a company, and then conducting training for new employees or old employees. The way an organization recruits can affect the types of employees it hires, how they perform, and their retention rates (Breaugh, 2013). Employee performance is very important for all business enterprises in developed and developing countries.

Many contemporary organizations are placing a greater emphasis on their performance management systems as a way of producing higher levels of job performance. order to produce performance improvements is probably best achieved by directing the performance management system to promote employee engagement (Gruman \& Saks, 2011). Employee engagement is a broad construct that touches almost all aspects of human resource management as we know it today. If every piece of human resources is not handled appropriately, employees fail to fully engage in their job in response to such mismanagement. The employee engagement construct builds on the foundation of previous concepts such as job satisfaction, employee commitment, and organizational citizenship behavior. Although related to and encompassing these concepts, employee engagement has a broader scope. Employee engagement is a stronger predictor of positive organizational performance indicating a two-way relationship between employer and employee compared to the previous three constructs: job satisfaction, employee commitment, and organizational citizenship behavior. Engaged employees are emotionally attached to their organization and deeply engaged in their work with great enthusiasm for the success of their company, working harder outside the contractual agreement. (Kompaso \& Sridevi, 2010). 
Muhammad Yusuf.; Analysis of Employee Recruitment in Improving Performance ...| 65

\section{CONCLUSION}

The recruitment process for hotel employees in the City of Pare-pare is not following the standards that should be carried out by a company, including the accommodation service business. This can be proven that the employee recruitment system in the hospitality sector in the City of Parepare is not carried out openly so that obtaining employees who do have the competencies needed in the hospitality industry is not achieved. From the aspect of hospitality education qualifications are still low. This means that there are still many hotels that do not pay attention to the need for labor and the qualifications of the type of education needed in the tourism industry, especially in the hotel sector. Meanwhile, there are still many aspects of employee performance that need to be improved considering that from several hotels visited, there are many fundamental matters that must be addressed, among others; aspects of a smile, greetings, and greetings of each employee, especially those working in the front office, still do not understand what exactly should be done when receiving guests. Likewise, in the lobby area, there are still some hotels that place items that are not designated by the hotel.

\section{REFERENCES}

Almeida Garcia, F. (2014). A comparative study of the evolution of tourism policy in Spain and Portugal. In Tourism Management Perspectives. https://doi.org/10.1016/j.tmp.2014.03.001

Andraz, J. M., Norte, N. M., \& Gonçalves, H. S. (2015). Effects of tourism on regional asymmetries: Empirical evidence for Portugal. Tourism Management. https://doi.org/10.1016/j.tourman.2015.03.004

Arhas, S. H., \& Suprianto, S. (2020). The Effectiveness of 6M Implementation at Artebo MSME. Jurnal Ad'ministrare, 6(2), 249-256.

Binns, T., \& Nel, E. (2002). Tourism as a local development strategy in South Africa. Geographical Journal. https://doi.org/10.1111/1475-4959.00051

Bojanic, D. C. (1996). Consumer perceptions of price, value and satisfaction in the hotel industry: An exploratory study. Journal of Hospitality and Leisure Marketing. https://doi.org/10.1300/J150v04n01_02

Breaugh, J. A. (2013). Employee recruitment. In Annual Review of Psychology. https://doi.org/10.1146/annurev-psych-113011-143757

Browning, V., So, K. K. F., \& Sparks, B. (2013). The Influence of Online Reviews on Consumers' Attributions of Service Quality and Control for Service Standards in Hotels. In Journal of Travel and Tourism Marketing. https://doi.org/10.1080/10548408.2013.750971

Chow, S., \& Chapman, D. (2013). Gamifying the employee recruitment process. ACM International Conference Proceeding Series. https://doi.org/10.1145/2583008.2583022

Culpan, R. (1987). International tourism model for developing economies. Annals of Tourism Research, 14(4), 541-552. https://doi.org/10.1016/0160-7383(87)90070-3

Cunha, L. (2011). Desenvolvimento do Turismo em Portugal: Os Primórdios. Fluxos e Riscos Revista de Estudos Sociais. 
Dahlan, D., Hasim, D., \& Hamdan, H. (2017). Pengaruh Manajemen Sumber Daya Manusia dan Budaya Organisasi Terhadap Kualitas Pelayanan Pada Kantor Kecamatan Tamalate Kota Makassar. Jurnal Ad'ministrare: Jurnal Pemikiran Ilmiah Dan Pendidikan Administrasi Perkantoran, 4(2), 69-75.

Ernawati, N. M., Arjana, I. W. B., \& Sitawati, A. A. R. (2019). Tourist Accomodation: A HostTourist Matched for Batur Geotourism. Indonesian Tourism and Development Studies.

Forsyth, T. J. (1995). Tourism and agricultural development in thailand. Annals of Tourism Research. https://doi.org/10.1016/0160-7383(95)00019-3

Gruman, J. A., \& Saks, A. M. (2011). Performance management and employee engagement. Human Resource Management Review. https://doi.org/10.1016/j.hrmr.2010.09.004

Ibrahim, R., Boerhannoeddin, A., \& Kazeem Kayode, B. (2017). Organizational culture and development: Testing the structural path of factors affecting employees' work performance in an organization. Asia Pacific Management Review, 22(2), 104-111. https://doi.org/https://doi.org/10.1016/j.apmrv.2016.10.002

Indonesia, C. (2016). Presiden Jokowi Tegaskan KL untuk Dukung Pariwisata.

Kencana, P. N. (2020). The Effect of Price and Service Quality on Customer Satisfaction of PT Huda Express Courier Services at Mcdonald's Bintaro Restaurant. Jurnal Ad'ministrare, 7(1), 29-38.

Kompaso, S. M., \& Sridevi, M. S. (2010). Employee Engagement: The Key to Improving Performance. International Journal of Business and Management. https://doi.org/10.5539/ijbm.v5n12p89

Kontogeorgopoulos, N., Churyen, A., \& Duangsaeng, V. (2014). Success Factors in Community-Based Tourism in Thailand: The Role of Luck, External Support, and Local Leadership. Tourism Planning and Development. https://doi.org/10.1080/21568316.2013.852991

Levitt, T. (1981). Marketing Intangible Products and Product Intangibles. Cornell Hotel and Restaurant Administration Quarterly. https://doi.org/10.1177/001088048102200209

Light, D., \& Dumbrăveanu, D. (1999). Romanian tourism in the post-communist period. Annals of Tourism Research. https://doi.org/10.1016/S0160-7383(99)00033-X

Liu, J. N. K., \& Zhang, E. Y. (2014). An investigation of factors affecting customer selection of online hotel booking channels. International Journal of Hospitality Management. https://doi.org/10.1016/j.jihm.2014.01.011

McGuffie, J. (1994). Accomodation: CRS development in the hotel sector. EIU Travel \& Tourism Analyst.

Nur, M., \& Seran, M. S. B. (2020). Service Quality of Border Region Higher Education Libraries. Jurnal Ad'ministrare, 6(2), 145-152.

Rakib, M., Rombe, A., \& Yunus, M. (2016). Pengaruh Pelatihan Dan Pengalaman Mengajar terhadap Profesionalitas Guru (Studi pada Guru IPS Terpadu yang Memiliki Latar 
Belakang Pendidikan dalam Bidang Pendidikan Ekonomi). Jurnal Ad'ministrare" Jurnal Pemikiran Ilmiah Dan Pendidikan Administrasi Perkantoran", 3(2), 1-148.

Rao, P. S. (2013). Impact of Service Quality on Customer Satisfaction in Hotel Industry. IOSR Journal Of Humanities And Social Science. https://doi.org/10.9790/0837-1853944

Rogerson, C. M. (2006). Pro-poor local economic development in South Africa: The role of propoor tourism. Local Environment. https://doi.org/10.1080/13549830500396149

Saayman, M., Rossouw, R., \& Krugell, W. (2012). The impact of tourism on poverty in South Africa. Development Southern Africa. https://doi.org/10.1080/0376835X.2012.706041

Schubnell, T., Meuer, L., \& Bengtson, R. (2008). Improving Surgical Services Performance Through Changing Work Culture. AORN Journal, 87(3), 575-583. https://doi.org/https://doi.org/10.1016/j.aorn.2008.02.017

Sheldon, P. J. (1989). Professionalism in tourism and hospitality. Annals of Tourism Research. https://doi.org/10.1016/0160-7383(89)90004-2

Sriprasert, P., Chainin, O., \& Rahman, H. A. (2014). Understanding Behavior and Needs of Halal Tourism in Andaman Gulf of Thailand: A Case of Asian Muslim. Journal of Advanced Management Science. https://doi.org/10.12720/joams.2.3.216-219

Sujatno, A. B. (2011). Hospitality Secret Skills, Attitudes, and Performances for Restaurant Manager. Edisi Pertama. Yogyakarta: Penerbit ANDI.

Tsang, N., \& Qu, H. (2000). Service quality in China's hotel industry: A perspective from tourists and hotel managers. International Journal of Contemporary Hospitality Management. https://doi.org/10.1108/09596110010339706

Walker, M., Kaplanidou, K., Gibson, H., Thapa, B., Geldenhuys, S., \& Coetzee, W. (2013). “ Win in Africa, With Africa": Social responsibility, event image, and destination benefits. The case of the 2010 FIFA World Cup in South Africa. Tourism Management. https://doi.org/10.1016/j.tourman.2012.03.015

Waris, A. P. M. dan A. (2015). Effect of Training, Competence and Discipline on Employee Performance in Company (Case Study in PT. Asuransi Bangun Askrida). Procedia Social and Behavioral Sciences. https://doi.org/10.1016/j.sbspro.2015.11.165

Yousaf, S., \& Xiucheng, F. (2018). Halal culinary and tourism marketing strategies on government websites: A preliminary analysis. Tourism Management. https://doi.org/10.1016/j.tourman.2018.04.006 
68 | Jurnal Administrare: Jurnal Pemikiran Ilmiah dan Pendidikan Administrasi Perkantoran Volume 8 Issue 1, January-June 2021. Pages 59-68

This page is intentionally left blank 